\title{
Drought Resistance and Constancy of Osmotic Ascension caused by Wilting in Soybeans*
}

\author{
By Yasona FuKUdA** and Shosuke KAKU \\ 福田入十楠, 賀来章輔：大豆の调萎飞よる滲透圧上昨の固定之耐乾性
}

Received April 11, 1952

In the former reports (33) the authors affirmed in soybean plant, as other plants $(1,13,23,29,31,32,37,38,41)$, the one grown on drought spot has higher osomtic value than the one grown on moist place. But they observed that the temporary drought resistance, which acquired on extremely dry spot in hot season, relaxates in cool season. Fortunately some of these samples were studied to see the regulation of osmotic value by subjecting them to wilting. Temporary wilting is believed to give the plant drought resistance $(16,42)$, like the temporary cold resistance ( 30 , $31,35,39,40)$.

Whether the experience of former drought, which has influenced to increase the cell sap concentration $(6,7,34,36,43)$ still effects osmotic ascension or not on the part produced from the growing point after the soil moisture is regained is a problem not yet investigated.

\section{Material and Methods}

The material is a autumn-soybean Tamanishiki which is the same in Rep. 1. The plants were grown in cyrindric, galvanized iron pots $15 \mathrm{~cm}$ in diameter and $17 \mathrm{~cm}$ height. The soil used was sandy loam and the saturated water capacity of this soil was estimated approximately $26 \%$. A watering tube containing crushed stone extended down the side of each pot to the bottom. The pots were divided into two groups of $80 \%$ and $50 \%$ of water capacity, and the pots were weighed daily and adjusted by watering. The pot of $80 \%$ water capacity which had been subjected to wilting stopped being watered, and in several days it reached near the point of permanent wilting. After that the soil was once more watered to regain the optimum soil moisture, $80 \%$ of water capacity.

\section{Experimental Results}

\section{Experiment 1. Ascension of Osmotic Values}

Example A) Control plants grown in constant soil moisture. The results (Fig. 1) are described in the former report (33).

\footnotetext{
* The problem of physical and physiological dryness by Y. FurudA (Report 2)

** Botanical Institute, Faculty of Science, University of Hiroshima. The authers express their gratitude for the promote fund from ihe Ministry of Education given for the study of this problem,
} 
Example B) Plants wilted 4 times. After the plant in $80 \%$ soil moisture had been wilted four times, the soil moisture held $80 \%$ constant (Fig. 1). For 70 days, from Sept. 6 when the flowers fell to the middle of Nov. when the plant withered, the osmotic value did not show much fluctuation, only increasing a little as the season advanced. The curve is always higher $(0.51-0.47=0.04 \mathrm{~mol})$ than that of

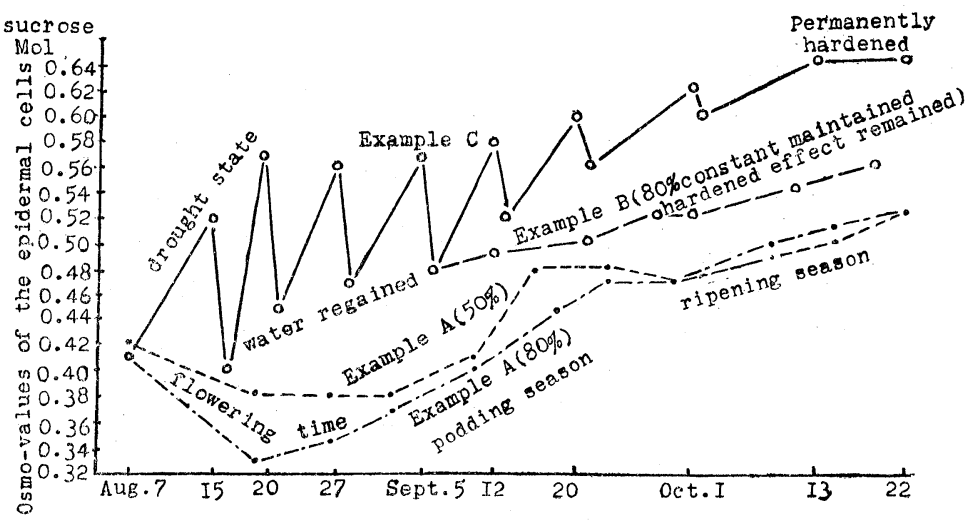

Fig. 1. From the late growing season to the ripening period.

the control A), in spite of both plants growing at $80 \%$ moisture condition. It may be considered that the effect of hardening remains all through the life. The real water content of the soil where the wilted example grew was calculated as $50 \%$ by the bisection of the four triangles of moisture variaton at wilting. The plant grown in 40 or $50 \%$ soil moisture (illustrated in Report 1) has $0.04 \mathrm{~mol}$ higher osmotic value than that grown in $80 \%$ moisture after the flowers have fallen. Therefore the hardening effect of wilting four times corresponds with the effect of the different conditions of $80 \%$ and $40 \%$ constant moisture.

Example C) Plants wilted 8 times. As seen in Fig. 1, at the flowering time both Exaple B) and C) were subjected to wilting 4 times. The osmotic value rises at the wilting and drops at the recovering. But the curve of mean values ascends as wilting repeats. From Sept. 6, the samples were divided into two, i.e., B) and C). The C) plant was subjected to wilting continuously. The ascending tendency of the mean osmo-value is also maintained, but the degree of dropping resumed by recovering becomes less and less as the experience repeats. After the 8th wilting the minimum becomes equal to the maximum and so fixes (Fig. 1). By these examples it is confirmed that the effct of repeated wilting builds up an acquired character which makes plasm contain the hypertonic cell sap through the life.

Example A and B) In Fig. 2 are illustrated osmotic variations of all the leaves from the lowest to the uppermost of the plant B), grown on $80 \%$. for 40 days after being wilted 4 times, and those of the control A) on constant $80 \%$. The lowest 5 leaves had dropped when the observation began. Up to the 13th leaf, B) is $0.04 \mathrm{~mol}$ 
higher and above that $0.06 \mathrm{~mol}$ lower than A). The lower leaves of B) are the ones which have grown during the season when wilting repeated, but the upper leaves are the ones which have developed after the normal water condition was regained. It indicates that the new shoot which sprouted from the rejuvenated growing point

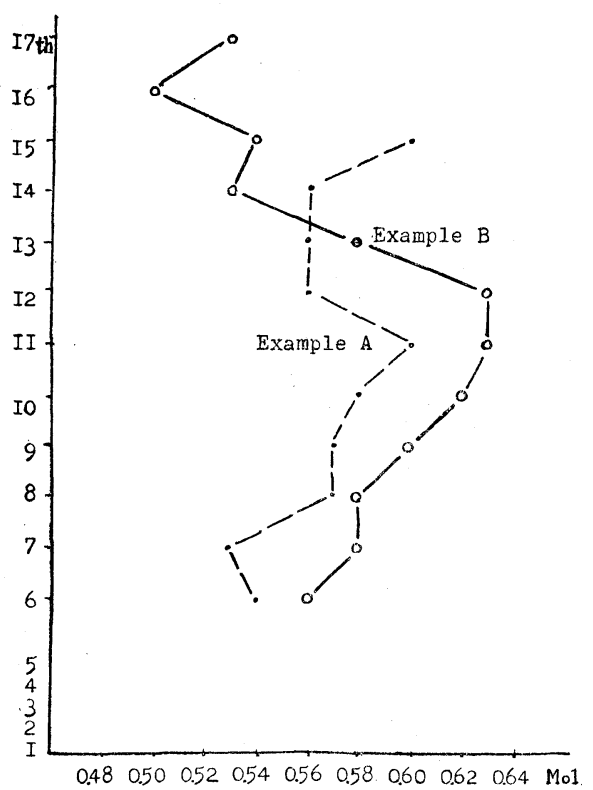

Fig. 2. Osmo.values of the epideamal cells. of the hardend plant adapts to regained condition, and the experience of the former water economy does not effect any more. Like a young shoot in the early stage of growth, the rejuvenated shoot of B) has much lower osmotic value than that of an adult shoot of $\mathrm{A}$ ).

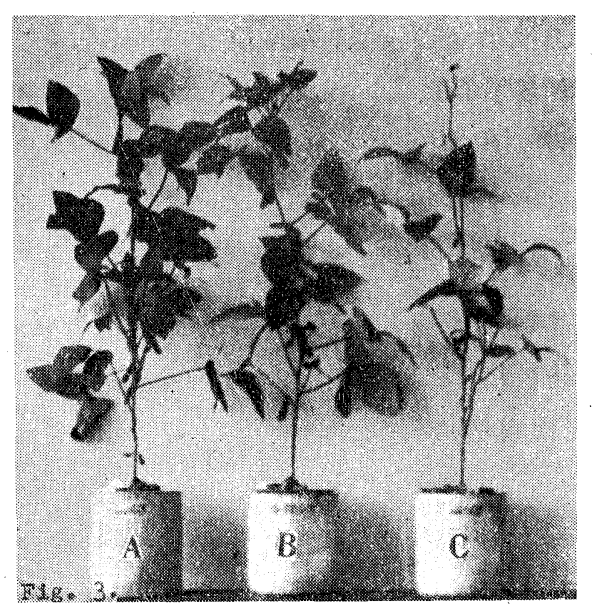

Experiment 2. Outer Morphological Differences of the Hardened, the Rejuvenated after being Hardened and the Nonhardened (Fig. 3)

The forms of the plants grown in the constant water condition, 100, 80 and $65 \%$ have the same size, but when moisture becomes less than $65 \%$ then the plants become dwarf.

Table 1. The result of growth and the yield on Nov. 5 .

\begin{tabular}{|c|c|c|c|c|c|}
\hline Soil moisture & $\begin{array}{c}\text { Height of } \\
\text { the plant }\end{array}$ & Nos. of pods & $\begin{array}{c}\text { Nos. of } \\
\text { beans }\end{array}$ & $\begin{array}{c}\text { Weight of } \\
\text { total beans }\end{array}$ & $\begin{array}{c}\text { Weight of } \\
\text { a bean }\end{array}$ \\
\hline $80 \%$ & $73 \mathrm{~cm}$ & 21 & 36 & $75.5 \mathrm{~g}$ & $0.21 \mathrm{~g}$ \\
50 & 62 & 17 & 20 & 46.0 & 0.23 \\
$\begin{array}{c}80, \text { but 4 wilt } \\
\text { (av. 50) }\end{array}$ & 70 & 22 & 29 & 78.0 & 0.28 \\
$\begin{array}{c}80, \text { but 8 wilt } \\
\text { continued }\end{array}$ & 71 & 1 & 1 & - & - \\
\hline
\end{tabular}


On the other hand the example of 4 times wilting $B$ ) is as tall as that on constant $80 \%$ (Fig. 3). The 4 times wilting does not effect growth if the standard soil moisture is kept at $80 \%$ both before and after the wilting; 8 times wilting also does not effect growth (Tab. 1); if it does, it causes the shedding of leaves and makes the plant look poor (Fig. 3). Even the plant wilted 4 times looks more prosperous when a new shoot grows from the rejuvenated top. Even the same average amount of variation is given in the soil, when it is kept constant or when it varies, it gives different effect on plants.

Experiment 3. Drying Speed of Leaves According to the Order of Position Estimated by the Way described in Rep. 1

In A) the position of leaves has nothing to do with the surface developement (Tab. 2), but $\mathrm{k}$ ) and $\mathrm{kn}$ ) are larger in the upper leaves. Stronger physical transpiration in the upper leaf than in the lower, denoted by the value $\mathrm{k}$ ), is due to the

Table 2. Drying speed of leaves of Axample A) on Nov. 5.

\begin{tabular}{|c|c|c|c|c|}
\hline Leaf position & $\begin{array}{c}\text { Surface deuelope- } \\
\text { ment (s.d.) }\end{array}$ & $\begin{array}{c}\text { Drought coeffi- } \\
\text { cient (k) }\end{array}$ & $\begin{array}{c}\text { Normal coeffi- } \\
\text { cient k/s.d.=kn }\end{array}$ & Ecotype \\
\hline 8 th & 6.900 & 0.0452 & 0.00650 & Hardened \\
9 & 5.900 & 0.0535 & 0.00909 & $\vdots$ \\
10 & 6.700 & 0.0811 & 0.01205 & $\vdots$ \\
11 & 6.900 & 0.0940 & 0.01361 & $\vdots$ \\
12 & 6.300 & 0.1220 & 0.01940 & $\vdots$ \\
15 & 5.850 & 0.1690 & 0.03151 & Non-hardened \\
\hline
\end{tabular}

water passability of the leaf surface $\mathrm{kn}$ ) and not to the surface development of a leaf. It suggests that the drought resistance does not differ with the seasonal changes but differs according to the age of leaves; that is, the older the leaf is the less the water passability of a leaf becomes. In Example B) (Tab. 3) the 8-12th leaves which developed during wilting treatment have small passability like the oldest leaves of the control, which suggests that the former had been hardened.

Table 3. Drying speed of leaves of Example B) (4 wilt) on Nov. 5.

\begin{tabular}{|c|c|c|c|c|}
\hline Leaf position & $\begin{array}{c}\text { Surface } \\
\text { development }\end{array}$ & $\mathrm{k}$ & $\mathrm{kn}$ & Ecotype \\
\cline { 2 - 5 } & 6.200 & 0.0582 & 0.00938 & Hardened \\
12 & 8.250 & 0.0692 & 0.00838 & Do. \\
15 & 6.800 & 0.1384 & 0.02040 & Non-hardened \\
16 & 8.000 & 0.2350 & 0.02940 & Do. \\
17 & 6.300 & 0.3690 & 0.05820 & Do. \\
\hline
\end{tabular}


But in the leaves which grew after the normal water condition was regained, the surface development is not changed, but k) and kn) are very large and indicate that the ability of drought resistance is weak, showing that they are not hardened. In all the leaves of Example $C$ ) the value of three characteristics relating to the water economy do not differ much (Tab. 4).

Table 4. Drying speed of leaves of Example C) (8 wilt) on Nov. 5.

\begin{tabular}{|c|c|c|c|c|}
\hline Leaf position & $\begin{array}{c}\text { Surface } \\
\text { development }\end{array}$ & $\mathrm{k}$ & $\mathrm{kn}$ & Ecotype \\
\cline { 2 - 5 } 8 th & 6.350 & 0.0470 & 0.00738 & Hardened \\
9 & 7.500 & $0.052 \mathrm{~N}$ & 0.00701 & Do. \\
10 & 7.800 & 0.0581 & 0.00745 & Do. \\
11 & 8.000 & 0.0581 & 0.00730 & Do. \\
\hline
\end{tabular}

These values of Example C) are the same as those of the hardened ones in Example B). Every leaf of Example C) is hardened.

\section{Conclusion}

In the wilted examples the leaves which generated after the normal soil moisture was regained have lower osmotic value than that of the control and the leaves which developed during the treatment have higher osmotic value which is irreversible. Now coming to the drying speed of these leaves, the smaller $\mathrm{k}$ ) value in the latter old one suggests that it has acquired greater drought resistance. Now, the modification in osmotic value coincides with the acquirement of drought resistance. In Example $\mathrm{C}$ ), after 8 wilting the high osmotic value irreversibly remained and also the smallness of the drought coefficient $\mathrm{k}$ ) shows all leaves are strongly drought resistant. In Example A) which was kept in 80\% constant soil moisture, the 8th but now the lowest leaf alone is drought resistant. In each example the osmotic value and the three drought features of the uppermost leaves are as follows (Tab.5):

Table 5

\begin{tabular}{|l|c|c|c|c|c|}
\hline & $\begin{array}{c}\text { Osmotic } \\
\text { value }\end{array}$ & $\begin{array}{c}\text { Surface } \\
\text { development }\end{array}$ & $\mathrm{k}$ & $\mathrm{kn}$ & Ecotype \\
\hline Example A & 0.60 & 0.585 & 0.1690 & 0.3151 & Mesomorph \\
$\begin{array}{c}\text { Example B } \\
\text { regenerated one }\end{array}$ & 0.53 & 0.630 & 0.3690 & 0.5820 & Non-hardened \\
hardened one & 0.63 & 0.825 & 0.0692 & 0.0838 & Hardened \\
Example C & 0.64 & 0.800 & 0.0581 & 0.0730 & Hardened \\
\hline
\end{tabular}

Now, the modification of the irreversible increase of osmotic value and the decrease of water-passability through the leaf surface are acquired by wilting. In the publication of other writers the increase of osmotic value by wilting was recognized as 
the acquirement of the ability of drought resistance without exact testimony, but the present writers experimentaly confirmed that the leaves which developed during wilting treatment have acquired the drought resistance, and also the increase of osmotic value by wilting is an indication of the drought resistance. That the fixed hardening effect is recognizable in the leaves which developed during wilting treatment, is due to that the leaf growth is an irreversible phenomenon. The period of growth of a leaf, however, lasts longer than the drought duration, so that a leaf subjected to wilting may not develop to a morphoiogical xeromorph.

Water deficit of the soil effects the plant in the following manner:

1) Constant water defecit results the xeromorphic dwarfism of plant.

2) Temporary water defecit results the type hard to drought. The latter has not been hindered its growth as the former, but both have been hardened to drought.

3) The hardened leaf of the latter has large surface development and small water passability through the leaf surface. So that the leaf type which is hard to drought is not the xeromorph.

The high osmo-value and small drought coefficient and perhaps the large amount of solute may be indications of the drought resistance but are not the special features limited to the xeromorph.

\section{Literature Cited}

(1)-(28), are presented in the former Report 1): (33) in the list of literatures in this Report.

29. Drabble, E. \& Drabble, H., The relation between the osmotic strength of cell sap in plant and their physićal enviroment. Biochem. Jour. 2. 1907.

30. Dunn, S., Relation of hydrophillic colloids to hardiness in cabbage bussels sprout, and alfalfa plants as shown by dye adsorption test. Plant physiol. 8. 1933.

31. Fukuda, Y., Die anpassungsfähigkeit der Pflanzen bezuglich des Osmotischen Druckes. Bot. Mag. Tokyo. 51. 1935.

32. - Seasonal changes of hydrature features of the Manchurian woody plants, especially on the reserve materials. J. Sci. Hiroshima Univ. B. 1952.

33. Kaku, S., Hydrature Studies of Soybeans on the Soil Moisture Slope. Bot. Mag. Tokyo. 1952.

34. Iljin, W.S., Der Einfluss des Welkens auf den Ab- und Aufbau der Stärke in der Pflanze.

35. Harvey, R.S., Hardening process in plants and developments from frost injury. J. Agr. Res. 15. 1918.

36. Molish, H., Ueber den Einfluss der Transpiration auf das Verschwinden der Stärke in den Blättern. Ber. d.d. Bot. Ges. 39. 1921.

37. Ohga, I., Changes of osmotic concentration in certain plants. Bot. Mag. Tokyo. 40. 1926,

38. Reed, H. S., Growth and sap concentration. J. Agr. Res. 21. 1921.

39. Rosa, J. T. Jr., Investigation on the hardening process in vegetable plants Missouri Agr. Exp. St. Res. Bull. 48. 1921.

40. Scarth, G. W. and Levitt, J., The frost hardening mechanism of plant cells. Plant Physiol. 12. 1937.

41. Stoddart, L. A., Osmotic pressure and water content of prairie plants. Plant Physiol. 10. 1935.

42. Tumanov, I., Ungenugende Wassersorgung und des Welken der Pflanzen als Mittel zur Erhohung ihrer Durreresistenz. Planta 3. 1927.

43. Vassiliev, I. M. and Vassiliev, M. G., Changes in carbohydrate content of wheat plants during the process of hardening for drought resistance. Plant physiol. 11. 1936. 